\title{
Some Notes on the Folklore of the Algerian Hills and Desert
}

\section{W. Hilton-Simpson}

To cite this article: M. W. Hilton-Simpson (1922) Some Notes on the Folklore of the Algerian Hills and Desert, Folklore, 33:2, 170-199, DOI: 10.1080/0015587X.1922.9719238

To link to this article: http://dx.doi.org/10.1080/0015587X.1922.9719238

Published online: 01 Feb 2012.

Submit your article to this journal $\sqsubset$

Q View related articles $\llbracket$ 
SOME NOTES ON THE FOLKLORE OF THE ALGERIAN HILLS AND DESERT.

M. w. HILTON-sIupson.

IN the summer of 1914 I submitted to the Folk-Lore Scoiety a paper on "Some Algerian Superstitions," which was read during my absence in France and subsequently appeared in Folk-Lore (vol. xxvi. p. 225 et segq. September 1915). In it I attempted to lay before the Society some of the material collected by my wife and myself during two winters spent in wandering among the Shawiya Berbers, whose eerie-like villages are perched high amid the rocky hills of the Aures massif to the N.E. of Biskra, and among the nomad, so-called Arab, tribes who spend the winter with their flocks and herds in the desert at the southern foot of these hills, migrating northward to the central Algerian plateau in the summer, when lack of pasture drives them from the fringe of the Sahara. Since the War we have passed two more winters among these people, of whom we are endeavouring to prepare an ethnographical survey, and besides further notes upon their arts and crafts, medicine and surgery, etc., we have obtained a certain amount of additional information with regard to their customs and folk-lore. In order to present a carefully considered digest of this information, viewed in comparison with the folk-lore of other regions, a considerable time would obviously have to be spent in research work at home. $U_{p}$ to the present I have been unable to find the leisure to devote to this task, though I hope at some future date, 
after further enquiries in the field, to publish our results in full.

In the meantime I can attempt no more than to place before students of the manners and customs of primitive folk some of the raw material we collected, in the hope that this may prove of interest to them in their comparative studies. As was the case in our wanderings before the War, so during our subsequent journeys in the hills we made it a rule to be accompanied by no servants other than a native mounted orderly, whose services the French authorities have always kindly placed at our disposal, for "hangers on" to the European, engaged as servants in a tourist centre, are liable to cause unpleasantness with the simpler folk whose customs we wished to observe. Further, we always lived actually in the villages we visited, residing in the house of the Sheykh or a Marabout or other prominent personage, or, where none such existed, hiring a little stone-built Shawiya hut wherein to live and work. In this way we enjoyed better facilities for observing native life than would have come our way had we encamped outside the villages, and we have formed a large circle of acquaintances. This circle includes most of the influential Marabouts, or hereditary saints of the Aures and its vicinity, as well as a number of scribes (Tolba ; singular, taleb) who practise the magic art and-owing to the presence of my wife-some women who live, in the guise of sorceresses, upon the credulity of their neighbours. Had I been alone I could not have hoped to gain the confidence of the women who, being Moslems, would naturally avoid the male stranger : as it was I did not lack opportunities of observing many of their customs.

From these writers of charms and general practitioners of the magic art we gleaned some information as to the nature and habits of the Jenun (in the singular, Jinn) whose supposed existence plays so important a part in Algerian superstition, and whose main characteristics the following 


\section{i72 Folklore of the Algerian Hills and Desert.}

notes may serve to illustrate. Of these demons, whose name Jenun Professor Westermarck ${ }^{1}$ has explained as imply. ing no more than " secret " or " mysterious," some appear constantly to seek opportunities of working mischief in the affairs of men, others remain quiescent until they are disturbed by mortals, while some seem to exercise a beneficial and even moral influence upon mankind.

An example of the last-named type of Jinn is to be found in the belief of the Arabs of the desert oases that every house contains a spirit which remains unseen as long as the inhabitants of the house behave themselves properly, but which appears to them usually in the form of a woman should they begin to take to evil courses, and warns them that if they persist in their bad ways it will kill or ruin them. A cruel stepmother of El Kantara is believed to have been done to death by such a Jinn. Doubtless these warning demons are Moslems, for, as we shall see, the denizens of the underworld are no strangers to religion.: indeed the conversion of pagan Jenun to the faith of Mohammed is several times mentioned in the Koran, and an instance referred to there of such converts returning to. their own kind in the capacity of "warners." "

Some Jenun are said to possess and exercise the power of healing. Thus there is a jujube bush (Ziryphus lotus) near the oasis of El Kantara which is believed to be inhabited by a female Jinn, which appears only at night. Mothers of ailing children burn candles and incense (benjoin) beneath this bush, inviting the aid of its spirit to cure their little ones, and they continue these offerings in gratitude. every Friday should their prayers be heard and theirchildren restored to health with the assistance of the Jinn.

1 Westermarck, "The Nature of the Arab Ginn," Journal Anth. Inst. xxix. 268. . [For the Jinn see Herklots, Islam in India, Oxford, I92 ${ }_{4}$ p. 218 et seqq. -ED.]

- Koran, Rodwell's trans. Sura 46, verse 28. 
The malevolent spirits which occupy blood spilled upon the ground are not aggressive unless disturbed. Should a mortal accidentally step into or over a pool of blood its Jinn will enter into him, with the result that he will fall ill or suffer some reverse of fortune; but it seems that the spirit will not leave the blood to attack a person who carefully avoids touching it. Blood spilled, however, should immediately be covered with earth. It appears that I myself have offended a number of Jenun and am now suffering in consequence. This circumstance was brought to my notice two years ago by my friend Mr. P. P. H. Hasluck, who learned of it in conversation with some Arab friends. These people stated that my thinness is due to the fact that I am in the habit of spending a good deal of time in hunting the Barbary sheep and the two species of gazelle obtainable in the neighbourhood of El Kantara. These, with all other wild animals, are the property of Jenun who, annoyed at my disturbance of their cattle, are causing me to lose flesh, and will, doubtless, eventually destroy me unless I give up shooting.

Empty houses are a favourite resort of Jenun, who are apt to resent intrusion into them. The grandfather of one of my El Kantara friends was once asked to sleep in such a house for its protection. In the night a female form, attired in a black robe, appeared and forthwith attacked him, hitting him a heavy blow on the thigh. Had he not invoked the aid of a Moslem saint, whose tomb is in the oasis of El Kantara and who himself sometimes appears in the shape of a lion by night, he would have been slain by his assailant, even as it was the wound in his thigh suppurated for six months and was only cured as a result of visits to the saint's mosque every Friday.

Some Jenun are very easily provoked to acts of violence. An Arab who was unable to send home before nightfall the whole of the dates which he had gathered during the day, remained all night in his garden to protect the fruit that 


\section{74 Folklore of the Algerian Hills and Desert.}

was left, wiling away the time by playing to himself upon the end-flute of reed. A passing Jinn, in the guise of a woman, growing weary of his music, fell upon him and slew him by cutting his throat. If it is dangerous to disturb the habitat of usually quiescent Jenun, to irritate them, or to slay their animals, it is doubly 80 to attack or interfere with them should they make themselves visible to mortal eyes. One night an Arab saw a woman, gorgeously apparelled and wearing golden ornaments, walking alone in a date grove. Thinking that he had chanced upon a splendid opportunity of robbing a defenceless female, he attempted to seize her. She thereupon fled, and the Arab, failing to realize that he was dealing with a Jinn, gave chase through the gardens until the female form fled under a little aqueduct of palm stem too low to admit of her pursuer's passage, with the result that the latter struck the palm stem so hard with his forehead as he ran that he was laid up for a considerable period. Another native of the same place, El Kantara, finding a fine he-goat in his garden took it home to the courtyard of his house. His wife instinctively took a dislike to the animal, pronouncing it to be a Jinn. In this she was correct, for the creature grew to a prodigious size and finally attacked her before it was driven from the house.

It is believed that Jenun are subject to death, but the mortal who slays one must himself expect to perish in a few days or, at least, to be ill for many months. It appears that a Jinn, when shot, utters a remarkably loud shriek, and that, no matter in what shape it may have revealed itself when shot at, its corpse will resemble that of a frog.

The injury which Jenun cause to the health of mortals is of so varied a character as to embrace practically every accident and illness which flesh is heir to, and, as I have noted in my former paper, ${ }^{1}$ armies of these demons are

1 Hilton-Simpson, "Some Algerian Superstitions," Folk-Lore, vol. xxvi. p. 245. 
believed to cause epidemics, striking down by scores and hundreds the inhabitants of the villages they attack. In the winter of 1918-19 a very serious outbreak of influenza at Djemora, the central village of one of the sub-tribes of the Ulad Zian nomads, was attributed to Jenun, but I have heard no suggestion that this attack was provoked by the people as were the attacks on individuals referred to above. In describing to me the origin and uses of written charms as protection against Jenun, a well-known Shawiya writer of these amulets gave me some details of the organization of the demon world.

He stated that he had learned from old Arabic books, mainly from the Taj el muluk of Mohammed ben el Haj el Kebir (who wrote on a great variety of subjects in addition to magic), that once, when wandering alone by night, Mohammed the Prophet encountered an old, ugly, and gigantic woman whom he rightly guessed to be a Jinn. Upon the Prophet mentioning the name of Allah, the woman evinced signs of fear. She then informed him that her title was "Mother of the Night," and that she was accustomed to slay and devour mortals and to destroy their flocks and herds. She further stated that she was chieftainess of all the Jenun, who wrought mischief at her behest, but that if the followers of Mohammed would wear upon their persons certain written charms, her minions would leave them unharmed, and that the wearer of such charms could even dispense with the invocation of Allah when he met a demon. " Mother of the Night" is assisted in her control of the Jenun by a male demon, by name Dokuyush, who acts as her chief of staff, and by one thousand subordinate officers or "elders." When the possessor of a written charm is about to undertake an enterprise or finds himself in any difficulty he merely taps his amulet, when Dokuyush immediately applies to "Mother of the Night" for instructions. The chieftainess, thus reminded of her promise to Mohammed, ordains that her 


\section{Folklore of the Algerian Hills and Desert.}

unseen followers shall not only allow the wearer of the amulet to go his way unharmed, but shall assist him until he proves successful in his undertaking or overcomes the difficulties which beset him. Thus we find that the wearing of a written charm is capable of turning otherwise malevolent and aggressive Jenun into useful helpers of mankind.

The charms themselves, which are infinite in their variety and appear to originate from the magical works of such authors as Suyuti, El Haj Tlemsani and Mohammed ben el Haj el Kebir rather than from the Koran, are naturally considered by the scribes who write them, for a fee, to be the only useful safeguard against Jenun with which man can provide himself. They are put to various uses. The majority, their characters written on paper (which it is important in some cases should not be "lined"), are worn enclosed in neat leather cases suspended from the necks of men and boys or in cases of silver, locally made, hung upon the breasts of women. But, as a cure for sore eyes, mystic words are written by a scribe upon a piece of eggshell, which is then enclosed in black rag (black being a colour distasteful to Jenun) and suspended over the affected eye from the headdress, to which it is attached by means of a penannular brooch universally worn by Algerian women, which brooch must have belonged to a deceased cousin or aunt of the sufferer and not to his or her mother or sister.

As I have pointed out in my previous paper, ${ }^{1}$ words are written on paper in the smoke of which, when burning, a patient is fumigated as a cure for fever among the Shawiya. I learned in 1920 of a variant of this treatment from the Arabs of an oasis for the cure of influenza and sore throat.

The patient goes by night to a cemetery and opens a very old grave. This must be done with the greatest secrecy, for the desecration of a grave is regarded as a

1 Folk-Lore, xxvi. p. 250. 
heinous crime, and a very ancient grave is selected in order to avoid disturbing the remains of a relative of a living member of the community, since such an act would, if discovered, probably lead to murder and the commencement of a blood-feud. From the tomb is removed the end nearest to the shoulder of the corpse's collar bone. This is then taken to a scribe, who writes upon it words which were detailed to me as follows: "Praise to God I O God I The only God I protect me and remove (i.e. the malady), for the sake of Mohammed the Prophet of God!" My informant, however, is illiterate, and so may well have been mistaken in the exact wording, whi h is scarcely likely to have been disclosed to him by a scribe who works for a fee.

This done, a fragment is broken from the bone and burnt, the patient fumigating his person in the smoke to cure the fever of influenza, and drinking in a draught of water the ashes of the bone so burned in order to cure the soreness of the throat. The rest of the bone, wrapped up so as to be concealed from view, is worn suspended around the neck in order to complete the cure. These charms, of course, are extremely difficult for a foreigner to obtain. Indeed it was only after I had been known to my informant for a number of years that I learned of its existence at all, and with difficulty that I persuaded him to try to secure a specimen for me. When he did succeed in bringing me one, the fragment of very old bone was later discovered to be probably that of a horse, so that I imagine the scribe who did the writing had his suspicions as to its ultimate destination, which was in fact the Pitt-Rivers Museum. As a remedy for fever which recurs every three days a human bone from a tomb similarly rifled is inscribed (by a professional writer of course) with the words "In the name of God I The Merciful the Compassionate!" and is worn around the neck. No particular bone however was suggested as being superior to others for the purpose, which is the prevention as well as the cure of the fever. 


\section{I8 Folklore of the Algerian Hills and Desert.}

Naturally the scribes who make money by preparing written charms deride the wearing of substances popularly supposed to be distasteful to Jenun such as rue, asafoetida, coral, iron, copper, pepper and salt, or which are believed to instil fear into the demon, subject as he is to death; for example, gunpowder, flattened bullets, vipers' heads, the bodies of scorpions and the canine teeth of dogs. They further state that the gesture of extending the fingers, accompanied by the remark "Five in thine eye" and the wearing of the gesture ready-made in the shape of a conventionalized silver model of a human hand, are equally useless in warding off the attacks of the Jenun whom all agree accompanies the envious glance known as the "Evil Eye."

Such methods in magic they characterize as old wives' tales, but these methods are nevertheless universally adopted by the Shawiya and the Arabs in addition to the wearing of written amulets.

The scribes, however, do consent to co-operate in the exorcism of Jenun by means other than the use of written charms. Should a person become possessed by a Jinn which he has disturbed by, for example, stumbling inadvertently into a stream or a pool of blood spilled upon the ground which it inhabits, a scribe is consulted with a view to ascertaining the religion of the demon. I have not yet found out how this is accomplished, but since it was a sorceress who informed me that a scribe should be called in, it would appear that the methods of divination employed by professional sorceresses themselves by means of either a spindle and a girdle or of a suspended spindlewhorl and two intersecting lines drawn upon an up-turned dish, both of which I described in my former paper, are inadequate to the task. When the scribe has pronounced upon this subject, a sacrificial meal is prepared upon a certain day of the week, the day and the colour of the victim, which should be a goat, though a fowl will suffice 
in poor households, depending upon the religion of the Jinn.

In the case of a Jinn of Jewish faith a red victim is sacrificed at sunset on a Saturday, the Jewish Sabbath : for a Moslem Jinn a white goat or fowl is slain at sunset on the Mohammedan Sabbath (Friday): while, should the Jinn be declared to be a Christian, a black victim is slaughtered at sunset on a Sunday. The victim must be of the sex opposite to that of the patient from whom its sacrifice is to remove the Jinn, and it is of importance that his colour should be without blemish. For a goat of absolutely uniform colour, therefore, people will pay a ridiculously high price when they require it for sacrificial purposes. From the goat or fowl a tasty dish is prepared of stewed flesh and semolina to which some natives state that nuts or fruit should be added, and this dish is left alone in a room for a short time before the patient and his family partake of it, maintaining the strictest silence as they eat. A portion of the dish, together with the blood of the victim, some of its bones and, in the case of a fowl, its feathers are placed in an earthen bowl and conveyed outside the village by a member of the family who must on no account speak or look behind him until he has regained the house after depositing the bowl, which with its contents is termed neshura, at some point usually just outside the village itself. Should he speak or look back, a Jinn will cause an accident to befall him. It appears that the neshura is usually so placed before the family consumes the meal. Some people say that only the bones, blood, and feathers of the victim should be placed in the bowl, but in the very numerous neshuras which I have observed I usually found traces of some of the meal as well.

Different natives with whom I have discussed the question appear to hold different opinions as to how this placing of a neshura outside the village causes the Jinn to leave the 


\section{Folklore of the Algerian Hills and Desert.}

person it has possessed. Some think that the mere placing of the bowl causes the Jinn to withdraw, others that the Jinn enters into any creature, for example, the ubiquitous half-starved dog, which may eat the remnants of the victim in the bowl. Either of these beliefs would account for the frequency with which neshuras are to be seen upon waste patches of land just outside the village and rubbish heaps, localities likely to be inhabited by Jenun and favourite scavenging places of the village dogs. Others say that the Jinn only leaves the patient to enter into anyone who inadvertently overturns or breaks the neshura, for which reason, no doubt, the bowls are so commonly to be found just beside the narrow lanes leading from the villages, often at corners of these lanes where the traveller might easily stumble upon one in the dark (the specimen I collected for the Pitts-Rivers Museum was found in such a spot). They are sometimes, indeed, though rarely, placed in the very centre of the narrow tracks themselves. Needless to say, the natives carefully avoid contact with a neshura, but some of them are in the habit of spitting at it as they pass, an action which apparently does not disturb the Jinn and cause it to possess the person who thus insults it. The sacrificial meal and the offering of a neshura to a Jinn is very widespread in Barbary, and has been noted by Professors Westermarck ${ }^{1}$ and Edmond Doutté ${ }^{2}$ in various regions of Algeria and Morocco. From what I was able to learn of it among the Berbers of the Aures and the Arabs of the surrounding plains, the differences in the details supplied to me by various informants arise from the fact that the natives follow the advice of a scribe or sorceress when a member of their family becomes possessed by a Jinn, and that the advice of these experts is based upon oral tradition. I do not think that there is any seal

1 Westermarck, "Nature of the Arab Ginn," Jowrn. Anth. Inst. vol. xxix.

'Dontte, Magie et Religion dans l'Afrique du Nord, p. 455. 


\section{Folklore of the Algerian Hills and Desert. 181}

difference in the beliefs of the two races, Berber and Arab, with regard to this method of freeing a patient from possession by a Jinn.

A curious means of healing a stye in the eye, which was described to me by an Arab of an oasis who practises the mediaeval Arabian medicine still persisting in and around the Aures, bears some superficial resemblance to the neshura, and may be intended to exorcise a demon who is troubling the patient, though I have no direct evidence that this is the case. The patient takes seven-a magical number-grains of barley in his hand and passes them with a rotary movement around the eye seven times, counting aloud. This done he takes some fragments of a broken pot to a point beside a path where he places a fragment of pottery on the ground and lays one of the grains of barley and a little salt upon it. He then places another potsherd on the grain and the salt and lays a second grain and some more salt upon it, continuing to erect a little pile of potsherds, barley, and salt until he has thus placed all his seven grains of barley in position. Any passer-by who recognises the little pile will upset it by throwing a stone at it, when the stye in the patient's eye will heal; the patient himself, however, must not so upset the pile.

A cure is effected should the pile be overturned by a wayfarer accidentally treading upon it, though I was not informed that possession by a Jinn or any other evil would befall the person who thus upset it. Sacrifices are made presumably to Jenun upon other occasions than the illness of a human being from whom a demon must be induced to depart. For example, when a new house is in course of construction, an animal must be slaughtered and eaten, and its blood smeared upon the lintel of the door when this is placed in position. The animal may be a cow, a sheep, or a goat, but an animal's blood must be smeared on the lintel and not the blood of a bird. People in very 


\section{Folklore of the Algerian Hills and Desert.}

humble circumstances sometimes cut a morsel from the ear of a living animal and apply blood from it to the lintel of the door from motives of economy, a substitute for the real sacrifice which is considered to be adequate. The father of one of my Arab friends, however, once decided that the slaughter of a dove would suffice when he was building a new dwelling. The best ram in his flock died immediately as a result of his meanness, for the substitution of the blood of a bird for that of an animal in this rite is considered to cause bad luck to attend the flocks of niggardly builders.

Jenun, of course, can be exorcised by other means than sacrifice. Certain scribes exist, at any rate among the Arabs of the plains, in the palms of whose hands a line known as Khatem (aring or seal), which I believe to be the heart line of European palmists, is especially pronounced. Such a scribe can exorcise Jenun in the following manner. He takes some extremely dirty wool cut from the hindquarters of a sheep, such as is sometimes used in Algerian medicine and surgery, some black earth, and the outer skin of a gall-nut. From these he prepares an ink with which he makes a large blot in the palm of the patient's hand. This blot he divides into four sections by means of two intersecting lines drawn across it, and in each section he traces certain mystic words containing some of the titles of Allah. He then proceeds to read passages from the Koran, whereupon the Jinn, speaking by the mouth of the patient, announces how much the scribe is to be paid for his work before actually leaving his victim. As the Koran is read the scribe can perceive the Jinn or, in serious cases, large bodies of Jenun moving out of the blot of ink like "troops on the march." When they have departed, the ink is washed off in water, which water the patient drinks. This method of exorcism serves to show how great a hold superstition retains upon the Algerian Arabs, persons who could scarcely be cheated out of a sou 
Folklore of the Algerian Hills and Desert. 183

in the ordinary affairs of life gladly paying the scribe the sum at which the Jinn itself is supposed to assess his services.

I recently noted two methods of foretelling the result of an illness which differ from those I noted before the War. A sorceress takes a large wooden ladle, such as is to be found in almost every Shawiya home, into which she puts some flour. To this she adds water without, however, stirring it, and then carefully pours away the water so as to leave the moistened flour in the ladle. Should the flour be left smooth, a favourable result of the illness is predicted; but should it form into lumps suggesting graves, the patient will die. In the latter event the invalid is not informed of the fate which awaits him ; but a satisfactory result is communicated to the sufferer. The second method of divination is concerned with a curious illness due, apparently, to the date of a child's birth. If two children are born in neighbouring houses in the same month but exactly fifteen days apart, e.g. on the first and fifteenth or the sixteenth and the thirtieth days of the month, one of them is certain to be sickly. In order to ascertain its fate its relatives dress up a stick to resemble a man, clothing it completely with sheshiya or red skullcap, gandura, a shirt, etc. This effigy they set upright beside a stream at a point where a barrage deflects the waters of the stream into a saqiya, or small irrigation canal. At the same time they place an egg in the water. The family visits the spot daily at dawn and sunset to see whether the effigy remains upright. Should it have fallen, the egg will be found to be bad and the child will die. On the day on which the effigy is placed beside the stream some barley is thrown upon the ground beneath the tripod which supports the waterskin in the home, ground rendered damp by the water dripping from the skin. This barley is allowed to grow and is cut three times. Should it grow strongly, the child will live; should it droop, the infant must die. My 


\section{Folklore of the Algerian Hills and Desert.}

informant could give me no reason underlying these practices ; but it may be that the effigy and the egg are believed in some way to indicate the child's fate, while the barley may be sown rather as a magical cure for the malady resulting from the unfortunate day of its birth than as a part of the method of divination.

On certain occasions mortals are especially liable to possession by Jenun, and magical precautions are accordingly taken to prevent it. One of these occasions is a boy's circumcision, at which time the Shawiya believe that a Jinn will make an attack upon him. Although the magical rites at a circumcision are by no means elaborate, I have thought it advisable to describe the whole ceremony as I saw it, for I have not yet found in the literature of the Barbary States any detailed account of a circumcision among either the Berbers or the Arabic-speaking people of the plains. In 1920 we were invited to attend the circumcision of two boys in a very small Shawiya hamlet at a short distance from the larger village of Beni Ferra in which we were staying. The household was an average one, neither wealthy nor very poor. When we arrived at about 8 a.m. a number of guests were present, among them many women attired in their best and wearing all their silver ornaments. One of these was a professional danseuse from the Ulad Abdi tribe, who had come to Beni Ferra to dance at several weddings which were taking place at the time. Before the man arrived who was to perform the operations, the women danced in the house to the strains of a single-membrane drum played by a man. At first two women, holding each other by one hand, danced opposite to three others (one of whom was the professional) also with joined hands, the two groups advancing to meet each other and retiring again backwards, as they moved their abdominal muscles in the usual Algerian danse $d u$ ventre. As they danced they continually chanted in the Shawiya, Berber, dialect: "God let his father live until 
Folklore of the Algerian Hills and Desert. 185

the little one grows big !"- the women who were watching them meantime uttering their long-drawn quivering cry of rejoicing to be heard at all Algerian festivals. These women danced for a considerable time and were at length relieved by two others, an elderly woman and a young one, who turned slowly round and round as they danced, holding their flowing garments outstretched with both hands. While the dancing was in progress the mother of one of the boys to be circumcised went behind the house with a basket and filled it with earth, which she sifted with her hands to remove stones and to break up hard lumps. At the conclusion of the dancing, the house in which it had taken place, containing but a single apartment, was divided into two by means of a carpet suspended as a curtain across it.

After the arrival of the operator, on one side of the curtain the grown-up men of the party-not the lads, of whom some were present-sat upon the ground and were offered a large dish containing some thin unleavened bread made with oil broken up into small pieces and garnished with numerous hard-boiled eggs, also broken up, and fragments of meat. This meal was merely tasted and removed immediately. A mat of halfa-grass having been laid upon the ground in the men's part of the room, a large wooden dish was placed bottom upwards upon it. This dish was thickly covered with the dry earth dug up by the mother of one of the patients, and a fragment of pottery placed beside it containing two fresh eggs and some lumps of coarse salt. A large quantity of powdered leaves of $\mathfrak{F} u n i-$ perus phoenicea and of powdered goat's dung, wrapped in cloths, were also placed at hand. The operator, who was not one of the professional practitioners of medicine and surgery whose work I have described elsewhere, ${ }^{1}$ squatted beside the dish on the left of the patient, a boy of eleven months, who was laid upon his back on the earth covering

1 Hilton-Simpson, Arab Medicims and Surgery, 1922. 


\section{Folktore of the Algerian Hills and Desert.}

the dish, his garments tied up, and was held in position by a man squatting on his right, the latter supporting the child's body with his left hand and holding its legs extended with his right. The foreskin having been drawn over a small knobbed stick, to which it was secured with string, and the glans protected by means of a loop of wool, the foreskin was severed at one cut with a sharp knife, a gun being fired outside the house the moment the cut had been made in order, as the natives said, to scare away Jenun. One of the fresh eggs upon the fragment of pottery was immediately broken open at one end and applied to the part, so that the penis was enclosed in it; after the removal of the egg, powdered juniper leaves were liberally besprinkled upon the penis, the abdomen, and the thighs, upon which melted butter was next poured. The sprinkling of juniper leaves was then repeated and considerable quantities of powdered goat's dung subsequently applied, after which more melted butter was poured on and covered with a final sprinkling of juniper. The child was then wrapped in its garments, and the man who had held it in position took some of the coarse salt in his right hand and made two series of seven rotary motions with it over the child's body-one series from right to left, the other from left to right-finally throwing some of the salt over the infant's head.

The ceremony of the first circumcision was then at an end. The second one exactly resembled it, save that the gun, an antiquated muzzle-loading weapon, could not be induced to go off for some moments after the cut had been made, a circumstance which caused considerable annoyance, probably owing to fear that a Jinn might have time to possess the child between the severing of the foreskin and the delayed discharge of the gun. The second infant was rather younger than the first. While the operations were being performed the women of the party kept up their chanting and dancing to the sound of the drum on 
the other side of the curtain, the mothers of the patients being the only women present upon the men's side. The mothers sat quiet in a corner, averting their eyes while the operations were carried out. Seated, as we were, upon an up-turned box within a few inches of the patient's head, we had an admirable opportunity of observing the actual operation in detail. The magical precautions taken to prevent possession of the infants by Jenun were the firing of the guns, a threat or warning to these demons, subject as they are to death, and the passing around the patient's body and the sprinkling over his head of salt, a substance well known to be disliked by Jenun in general.

The magical value, if any, of the dressings applied to the wound is, however, less easy to determine. At first glance it seems likely that the egg may be applied to the wound as being considered an emblem of fertility. But Professor Westermarck in his very exhaustive researches into the marriage ceremonies of both Berbers and Arabs of Morocco ${ }^{1}$ has been unable to obtain evidence that the eggs which are used in those ceremonies-and, as we shall see, at Shawiya marriages as well-are so used as emblems of fertility at all; and I have found, during my investigations of the medicine and surgery of the Aures, that the white of a raw egg is used as a dressing for cuts and burns by natives who practise medicine and not magic. Melted butter is the dressing most commonly applied to all wounds in Algeria : the powdered leaves of Funiperus phoenicea are widely employed in medicine in the Aures: while the natives regard goat's dung as a valuable styptic. The dressings which I have described as used in circumcision, therefore, may well be considered to possess practical rather than magical values.

Persons are believed to be very liable to possession by Jenun on the occasion of their wedding. The wedding ceremonies of the Aures are very similar to those described

1 Westermarck, Marriags Coremonies in Morocco. 


\section{Folklore of the Algerian Hills and Desert.}

in such detail by Professor Westermarck from Morocco. ${ }^{1}$ There are, however, certain differences in detail between them, but my own notes on the wedding ceremonies of the Shawiya, though now fairly copious, are not yet sufficiently complete to warrant their publication in full. When the bride is to be brought to the bridegroom's house it is necessary that she should be clad in new garments, the gift of the bridegroom. As to the silver ornaments she wears on this occasion, it is sufficient that they should be new to her; those taken from a divorced wife being sometimes offered to her successor.

When dressing for her journey, her gandura or shirt, which should be white, must be put on her by a young boy; in order, I was definitely informed, that she may bear her husband sons or that she may be "kept long by her husband," two ways of expressing the same idea. When seated, heavily veiled, upon the mule which is to convey her to her husband's home, a small boy is made to. ride upon the saddle in front of her for, I was told, the same purpose. During her journey firearms are repeatedly discharged in order to scare away Jenun, who are supposed to be awaiting an opportunity to "possess" her. On arrival at her husband's door she is lifted from the mule and carried into the house by a man. As she reaches the door she is presented by a female member of the bridegroom's family with an egg, which she breaks upon the lintel of the door as she passes beneath it. In the Jebel Shershar, however, brides sometimes smear butter upon the door lintel instead of throwing an egg against it.

Professor Westermarck, in the conclusions drawn from his enquiries into Moroccan marriage ceremonies," states. that he has obtained from natives no confirmation of the apparently reasonable conjecture that eggs are used in theseceremonies as being emblematic of fertility. The Shawiya

1 Westermarck, Marriage Coremonies in Morocco.

- Westermarck, Marriage Ceremonies in Morocco, p. 353. 


\section{Folklare of the Algerian Hills and Desert. 189}

with whom I have discussed the question have never told me in so many words that this is the reason underlying the use of eggs, but they state that the bride breaks an egg on the door lintel of her new home in order that she may long remain in that home, and it is hard to imagine how a sterile wife could hope to remain for any length of time in the home of a Shawiya husband. There are two points of resemblance between the wedding ceremonies of the Aures and those which take place at the commencement of ploughing, upon which latter I have published a few notes elsewhere. ${ }^{1}$ When the sacks of seed have been placed upon a mule for transport to the field, a small boy is made to ride upon them, and both at weddings and on the first day of ploughing a dish is prepared of semolina, butter, honey, and sugar, known to the Shawiya as ademine, which is offered to the guests at a marriage and to all and sundry who may be passing the field at the moment when ploughing is commenced. I have not yet learned from the natives themselves their reason for these customs, which appear to be universally observed in the Aures.

Other occasions on which human beings seem especially susceptible to possession by spirits, usually harmless if exorcised in time, are the periodical fêtes held in honour of the memory of some long since departed Marabout or Moslem saint. On such occasions persons of either sex, upon hearing the sound of the drums and hautboys which accompany the ceremony, work themselves up into a state of religious ecstasy. They become temporarily so demented as to lick hot iron, cut and stab themselves with knives, shriek, dance, prophesy, and disclose the deepest secrets of their neighbours, secrets which, it is believed, could only have been made known to them by some supernatural agency. This violent hysteria is usually followed by a collapse. The patient falls into a state of coma from which he or she can only be aroused by a recitation of

1 Hilton-Simpson, Among the Hill Folk of Algeria, p. $16 \mathrm{x}$. 


\section{Folklore of the Algerian Hills and Desert.}

some verses of Koran or with the assistance of certain people, skilled in magic, who by touching the crown of the patient's head three times restore him to consciousness.

When once the individual has recovered his senses after his outburst it is believed that all the scars which he may have inflicted upon himself in the course of his ravings will have disappeared. This religious hysteria is not confined to a tribe or sect, such as the Aïssawa who are renowned for their self-mutilation and who perform it for the edification of visitors in many a tourist centre of Algeria. It is said to overcome perfectly sane and rational persons at some of the zerdas or fêtes at the tombs of well-known marabouts. Such a zerda is that held about the month of August in honour of Sidi Yahia, whose tomb is situated midway between the railway "halte" of Maafa and the western entrance to the ravine of the same name, the only ravine which penetrates the western boundary of the Aures massif and thus connects the high-lying valley of Bu Zina with the outer world. A vast concourse of natives of both Berber and Arab stock attend this zerda from the Aures, from the surrounding desert, and even from such distant centres as Constantine. At the tomb of the saint, which is situated within a modern building erected by the French Government, much music and dancing takes place and, in dry seasons, prayers are offered for rain. When the ceremonies at the tomb are completed, a large number of people of both sexes betake themselves to the slopes of the holy mountain, known as the Jebel Bus, which lies on the right bank of the $\mathrm{Bu}$ Zina river just above its confluence with the Wad Abdi, that is to say, some half a dozen miles as the crow flies to the south-east of Sidi Yahia's tomb. Bringing with them candles and incense, they burn these upon the rocky slopes of the mountain upon which they pass the night, thus illuminating the hill, while music is provided by drum and hautboy, to the strains of which dance the men : very rarely, it is said, some women dance also. 
Folklore of the Algerian Hills and Desert. $19 \mathrm{I}$

Upon the morrow many of the crowd attend a large fair at Tagust, a Shawiya village situated at the north-eastern foot of the Jebel Bus, at which are sold goats, sheep and, especially, the dwarf cattle which are kept in very small numbers by the Shawiya.

The fête takes place at the moment when the fruits of the trees in the Abdi and $\mathrm{Bu} Z$ ina valleys are about to ripen. The ceremonies detailed above, according to descriptions given to me by several natives, Arab and Shawiya, who have assisted at them, are commenced as we have seen at the tomb of the Moslem saint, Sidi Yahia, an individual of whom it is reported that in his lifetime he turned a lion into stone (the stone somewhat resembling a recumbent lion is to be found beside the track leading from the tomb to the railway); and they are nowadays considered to have been originated at the death of this holy man, as a tribute to his honour and as a means of securing his supernatural help for the increase of rainfall in dry seasons.

Yet it seems more than possible that they may date from times of much greater antiquity, and afford an instance of the Islamization of the remnants of an older cult. It must be remembered that the Berbers of the Algerian hills were remarkably " superstitious" as well as determined warriors in the time of the seventh-century Arab invader, Oqba ben Nafi, who found it expedient to play upon their superstitions when he attempted their conquest and conversion to Islam, ${ }^{1}$ and, further, that in the early days of Arabian conquest the very soldiery who were extending the dominions of the Califate in Egypt and Africa by force of arms were themselves acquainted with little more than the mere formula of confession of their new faith." It is, therefore, reasonable to expect that a religion so introduced should absorb the existing cults of the Berbers

1 Dory, Moslems in Spain (tran. by F. G. Stokes, 1913). p. 129.

Dozy, op. cit. pp. 23 and 24. 


\section{Folklore of the Algerian Hills and Desert.}

rather than supplant them ; that the hill tribes of Algeria, doubtless as conservative in temperament thirteen centuries ago as they are to-day, should merely have clothed their ancient rites with a thin veil of Mohammedan orthodoxy rather than have abandoned them altogether. It seems that, at any rate in Phoenician times, the cult of a great goddess was very widespread in Libya, a goddess whose attributes included those of ancient deities of Egypt, Asia Minor, and Persia, and whom Herodotus connects with the Greek Athena. This goddess was Tanit, who appears to have been identical with the primitive Egyptian goddess Neith, the deity of nature, ${ }^{1}$ of water, of fertility, and of vegetation, the Mighty Mother of Sais in the Nile Delta, whose attributes were later assumed by Isis.

In the Geographical fournal (January 1922) I drew attention to a possible survival of the cult of this goddess in the Spring Feast of Menaa and the Abdi valley of the Aures, and to the apparent similarity between the game of " Koora," played on that occasion by the Shawiya women, and the strife of the Ausean maidens by the shores of Lake Tritonis (the Shotts of Southern Tunisia) as described by Herodotus." It may be that in the pilgrimage from the tomb of Sidi Yahia to the holy mountain, the Jebel Bus overlooking Menaa, and in the illuminations on that hill by night, we have another vestige of the cult of this goddess comparable, perhaps, to the Feast of Lamps at Sars (Herodotus, ii. 59-62) in honour of Isis Net. It is noteworthy that the modern feast takes place at the time when the fruits of the trees are commencing to ripen, a likely moment at which to propitiate a goddess of fertility, and that, in dry seasons, prayers for rain are said to be a feature of the ceremony, prayers which would naturally be addressed to a water deity. In addition to this it is, at least, remarkable

1 Sir E. A. Wallis Budge, Gode of the Ecyptians, i. 457.

Ibdd. 11.216.

2 Herodotus, iv. 180 . 
that on the day following the night spent on the mountain the crowd should attend a fair at Tagust in which the sale of cattle is an outstanding feature.

Now cattle are scarce in the Aures; too scarce, one would imagine, to render a special market desirable; for the material reason that the pastures of its valleys are insufficient to maintain large numbers of even the diminutive local oxen and cows. The flocks of the hill tribes, like those of the nomads, consist in sheep and goats. May it not be that in the cattle market referred to we have a survival, changed beyond all recognition in the lapse of time, of some ancient ceremonial in which the cow, sacred to Isis, played some part as did the gilt image of a cow at the Feast of Lamps at Sais ? Herodotus, describing the customs of the nomad Libyan tribes from Egypt to Southern Tunisia, states that in his time these people abstained from eating the flesh of cows, and remarks that "Even at Cyrêne, the women think it wrong to eat the flesh of the cow, honouring in this Isis, the Egyptian goddess, whom they worship both with fasts and festivals." 1

In the course of my investigations in the Aures before the War, when noting some curious family tabus among the Shawiya of the central valleys of the massif, I found that certain families consider it so unlucky for them to kill an ox or cow that, should a member of one of these families desire to slaughter such a beast, they call in a neighbour to do the actual killing, rewarding him for his pains with a portion of the meat, a custom which may possibly constitute a relic from days when in the Aures, as in the eastern districts of Libya, the flesh of the cow was not eaten by the natives out of respect for their principal goddess. In later times we find that Isis was definitely worshipped at Carthage, but her cult probably died out there, according to Bouchier, soon after the reign of Constantine, and the

2 Herodotus, iv. 186 (Rawlinson's trans.).

- Bouchier, Lifo and Lottors in Roman Africa, p. 81. 


\section{Folklore of the Algerian Hills and Desert.}

same author tells us that a shrine was set up to her in the second century A.D. by a legatus at Lambaesis, the great camp established on the plateau to protect the Roman farmers from the attacks of the mountaineers at a point no more than twenty miles to the north-east of the holy mountain, the modern ceremonies upon the slopes of which may, perhaps, be regarded as a fragment of evidence of the survival of her worship.

In certain other customs of the Shawiya traces of an ancient cult are to be found which would appear to refer to the early worship of Tanit in one or other of her aspects. Tanit, as we have seen, was a goddess of fertility. Bouchier states that she was "practically the same as the moongoddess Astarte." The very ancient shrine of Paphos is believed by Sir James Frazer ${ }^{1}$ to have been the seat of worship of a combination of two deities, a very early goddess of fertility and of Astarte, who was brought thither by the Phoenicians and who may have closely resembled the original goddess. These two, he considers, may have been "both varieties of that great goddess of motherhood and fertility whose worship appears to have been spread all over Western Asia from a very early time. The supposition is confirmed as well by the archaic shape of her image as by the licentious character of her rites ; for both that shape and those rites were shared by her with other Asiatic deities. Her image was simply a white cone or pyramid. In like manner, a cone was the emblem of Astarte at Byblus," etc. Now a white cone figures to-day in one of the love philtres employed among the Shawiya by young men and girls, and also by married women who wish to retain the affections of their husbands.

In a community such as the Shawiya, a Moslem community in which divorce is so easily obtainable, a sterile wife can hope for no prolonged residence in her husband's home ; the bearing of children, therefore, is her only safe-

1 Frazer, Adonis, Attis, Osiris, i. 34 . 
Folklore of the Algerian Hills and Desert. ${ }^{195}$

guard against early and sudden ejection. Although, doubtless, she is in complete ignorance of the reasons for and origin of the philtre she employs, she secretly mixes with her husband's food the summit of a cone of white sugar, an article of commerce procured from the large centres of civilization and to be found in every village of the Aures. With it she also mixes in the food another ingredient which I have specified elsewhere, while a man, should he desire to secure the affections of a woman, adds two other in. gredients to the point of the cone of sugar. ${ }^{1}$ I have as yet heard of no substitute for the sugar which might indicate the nature of the substance used in the philtre before such sugar was obtainable. Cone-sugar is the variety commonly employed to sweeten coffee, etc., but the sugar extensively used in practical medicine by the Shawiya doctors is of a different kind.

In discussing "Sacred prostitution in the worship of the Paphian Aphrodite and of other Asiatic goddesses," Sir James Frazer points out that in Cyprus " before marriage all women were formerly obliged by custom to prostitute themselves to strangers at the sanctuary of the goddess, whether she went by the name of Aphrodite, Astarte, or what not," and that a similar course was pursued in Phoenician and other temples.

It seems highly probable that a survival of some such custom is to be found in the notorious immorality of a Shawiya tribe, the Ulad Abdi, who inhabit a valley of the north-western Aures within eight miles of the holy Jebel Bus, among whom the tip of the sugar cone is used as a philtre and who celebrate the Feast of the Spring in the manner I have described in the Geographical fournal.

Sir James Frazer himself refers to the habits of these people, quoting from Professor Doutte the statement that when the French authorities attempted to interfere with

1 Hilton-Sînpson, " Some Arab and Shawiya Remedies," Journ. Roy. Antk. Inst. vol. xliii. p. 7I4. 


\section{Folklore of the Algerian Hills and Desert.}

their laxity of morals the people themselves offered strenuous opposition, "alleging that such a measure would impair the abundance of the crops."

My own notes on this subject, obtained during various visits to the Abdi valley, are as yet very scanty. Certain it is that many unmarried girls ard the very numerous divorcees of the tribe do lead an immoral life, that this is not regarded as in any way shameful by the majority of their fellow tribesmen-though a few are to be found who disapprove of it-and that, in the capacity of danseuses, these women pursue their calling in the villages of neighbouring tribes as well as in their own. So common is vice among these people that, in the surrounding country, to refer to women as Ulad $A b d i$ is equivalent to calling them prostitutes. It seems impossible that so marked a contrast should exist between tribes of a common origin as that to be found, in this respect, between the Ulad Abdi and their neighbours, unless it originates from the pursuit of some now forgotten religious observance, such as the worship of a goddess of fertility.

Yet it is extremely difficult to understand why such an observance should not have extended in the past to the kindred tribes around, or, if ever it did so extend, why it should have disappeared from among them and persisted in the Abdi valley, an area geographically no more or no less liable to outside influences than the valleys to the east or to the west of it.

I hope when I resume my researches in the field to glean further information, fragmentary though it must be, which may shed light on the origin of these customs of the Ulad Abdi, and also, if possible, of the Ulad Nail, a tribe of Arabic-speaking nomads who wander over the Sahara to the south-west of Biskra and whose customs are somewhat similar.

Assuming Bertholon and Chantre ${ }^{1}$ to be correct in re-

1 Bertholon and Chantre, La Berbdrie Oriexiale, p. 618. 
Folklore of the Algerian Hills and Desert. 197

garding the great goddess of fertility as also, in one of her aspects, a Moon-goddess, there seems little room for doubt that we have a further trace of the worship of Tanit in the preparation of the following philtre. Among both the Shawiya and the Arabs of the oases at the foot of the Aures are to be found women known as "Sorceresses of the Moon" whose services are sought by wives wishing to keep or regain the affections of their husbands. I have not heard that unmarried people consult them with a view to obtaining their philtres. The sorceress goes to a cemetery by moonlight, kindles a fire and digs up some bones of a very old corpse. These, with some benjoin and another incense known as bekhor es Sudan, she places on the fire. Having called upon Allah, she then colours her left eyelid with antimony, her lower lip with walnut, and her right hand and left foot with henna. The moon now begins to descend from the heavens and to approach a large, flat dish of water placed ready to receive it. As it comes the sorceress ties a cord of camel's hair around her waist and rolls upon the ground, imploring Allah to allow the moon to descend. He does so, and the moon enters the dish of water, "growling like a camel which is receiving its load" and producing upon the surface of the water a sort of thick froth or scum, the ground around meantime trembling with shocks of earthquake. The moon having been induced by incantations to return to its normal position and the earthquake having been stilled by the same means, the froth is skimmed from the surface of the water, and, when dried, is sold to applicants for admixture with their husband's food. Such is the preparation of the philtre by a Sorceress of the Moon exactly as described to me by persons who believe implicitly in its efficiency.

Dr. Mauchamp, ${ }^{1}$ a French medical officer, has given a somewhat similar but rather more detailed description of the rite as performed in Morocco. Among the more re-

1 Mauchamp, La Sorcellorio ax Maroc, p. 255 at seq. 


\section{Folklore of the Algerian Hucs and Desert.}

spectable of the Shawiya, deeds such as these of the sorceresses are regarded with pious horror, and a womani caught in the act of performing them would run a considerable risk of being killed on the spot. The subject, therefore, is a difficult one on which to obtain preciseinformation, and it is, perhaps, unnecessary to add that the natives themselves know nothing whatever of the origin of a custom which seems to find a counterpart in the drink: ing, for medicinal purposes, by the Mohammedans of Oude of water in which the moon has been reflected. From the few disconnected scraps of evidence set forth above it would appear that, beneath the modern cloak of Islam and under: lying the earlier chaotic demonology which pervades both the Aures and the desert to this day, there are to be found traces of an ancient cult the very existence of which is unsuspected by the natives who perform the last remnants of its rites. I am certain that careful enquiries in the field will reveal more such traces. But, if they are to be sought at all, the search for these traces must be undertaken at once. The forbidding frontiers of the Aures will at no far distant date be penetrated by roads ; work upon them has, indeed, been commenced. The stream of tourist traffic which the splendid scenery of the hills cannot fail to attract to these roads will surely have its effect in the introduction of modern ideas among the hitherto conservative Shawiya. In fact, the modernization of Berber life in the fastnesses of the Aures has already made more strides in the last three years than in any previous epoch.

This is due to the return from active service of numerous Shawiya who, had they not rallied round the standard of France in the Great War, would probably never have left their mountain homes at all.

As it is, they have come back to these homes, with widened outlook but with shaken faith, to sow the seeds of change in the customs of their neighbours; they have returned, worthier subjects of a Great European Power, 
Folklore of the Algerian Hills and Desert. 199

yet, to the student of folk-lore, they must appear as the vanguard of a destroying host.

I cannot conclude this paper without expressing my gratitude to the French Government and to all its officials we met with in Algeria for the facilities which have been granted to my wife and myself, and for the kindly cooperation and hospitality which we have ever received at their hands.

M. W. Hilton-Simpson. 